\title{
VARIABILITY OF DISTORTION PRODUCT OTOACOUSTIC EMISSIONS AT 10, 12, AND 16 KHZ: A PRELIMINARY STUDY
}

\author{
Edyta Piłka ${ }^{1,2}$, W. Wiktor Jędrzejczak ${ }^{1,2}$, Bartosz Trzaskowski ${ }^{1,2}$, Henryk Skarżyński ${ }^{1,2}$ \\ ${ }^{1}$ Institute of Physiology and Pathology of Hearing, Warsaw, Poland \\ ${ }^{2}$ World Hearing Center, Nadarzyn, Kajetany, Poland
}

Corresponding author: Edyta Piłka, Department of Experimental Audiology, World Hearing Center, Institute of Physiology and Pathology of Hearing, Mokra 17 Str., 05-830 Nadarzyn, Kajetany, Poland, Tel: +48 223560359 , Fax: +48223560 367, e-mail: e.pilka@ifps.org.pl

\begin{abstract}
Background: Distortion product otoacoustic emissions (DPOAEs) are usually measured up to $8 \mathrm{kHz}$. However some systems can measure DPOAEs up to $16 \mathrm{kHz}$. Therefore the aim of the study was to verify reliability of DPOAEs at 10,12 , and $16 \mathrm{kHz}$. The single- and multiple-fit options were compared.

Material and methods: DPOAEs were measured in subjects with normal hearing who had hearing thresholds better or equal to $25 \mathrm{~dB}$ HL for frequencies from 0.25 to $16 \mathrm{kHz}$. DPOAEs were measured at frequencies of $1,2,4,6,8,10,12$, and $16 \mathrm{kHz}$. The main focus was on the $10-16 \mathrm{kHz}$ range, while $1-8 \mathrm{kHz}$ served as a comparison. Each recording session consisted of three measurements. The first two were made consecutively without taking out the probe - single-fit mode. The third measurement was made after taking out and refitting the probe - multiple-fit mode.
\end{abstract}

Results: Results indicated that the inter-measurement variability was higher for frequencies in the $8-16 \mathrm{kHz}$ range than in the 1-6 kHz range. Additionally, the variability was higher when multiple-fit was used compared to single-fit.

Conclusions: Measurement of DPOAEs at frequencies higher than $8 \mathrm{kHz}$ seems reliable; however, DPOAEs at these frequencies have greater variability than those at lower frequencies.

Keywords: distortion product otoacoustic emissions $\bullet$ DPOAE • reliability • repeatability

\section{LA VARIABILIDAD DE EMISIONES OTOACÚSTICAS PRODUCTOS DE DISTORSIÓN EN 10, 12 Y 16 KHZ: UN ESTUDIO PRELIMINAR}

\section{Resumen}

Introducción: Emisiones otoacústicas producto de la distorsión (Distortion Product Otoacustic Emission - DPOAE) generalmente se miden hasta $8 \mathrm{kHz}$. Pero hay algunos sistemas que pueden medir DPOAE hasta $16 \mathrm{kHz}$. Por tanto, el objetivo del estudio fue comprobar la fiabilidad de DPOAE en los 10, 12, y $16 \mathrm{kHz}$. Se compararon también los mediciónes, en los cuales la sonda fue ajustada uno y múltiple veces.

Material y métodos: DPOAE se midieron en las personas con audición normal, cuales umbrales de audición fueron mejor o igual a $25 \mathrm{~dB}$ HL para frecuencias de $0,25 \mathrm{a} 16 \mathrm{kHz}$. Se midieron DPOAE en las frecuencias de 1, 2, 4, 6, 8, 10, 12, y $16 \mathrm{kHz}$. El foco principal estaba en el rango de 10 a $16 \mathrm{kHz}$, mientras que 1-8 kHz sirvieron de comparación. Cada sesión de medición se componía de tres mediciones. Los dos primeros se hicieron en forma consecutiva sin sacar la sonda - Modo de un ajuste solo. La tercera medición se realizó después de sacar y volver a colocar la sonda - Modo de un ajuste multíple.

Resultados: Los resultados indicaron que las diferencias en las mediciónes fueron mayor para frecuencias en el rango de 8-16 kHz que en el rango de 1-6 kHz. Además, las diferencias fueron mayor cuando se utilizó el ajuste múltiple en comparación con el ajuste solo.

Conclusiones: La medición de DPOAE a frecuencias superiores que $8 \mathrm{kHz}$ parece ser fiable. Pero DPOAE en estas frecuencias tienen una mayor variabilidad que en más bajas frecuencias.

Palabras clave: emisiones otoacústicas producto de la distorsión • DPOAE • fiabilidad • variabilidad 


\section{ИЗМЕНЧИВОСТЬ ОТОАКУСТИЧЕСКИХ ЭМИССИЙ НА ЧАСТОТЕ ПРОДУКТА ИСКАЖЕНИЙ ДЛЯ 10, 12, И 16 КГЦ: ПРЕДВАРИТЕЛЬНЫЕ ИССЛЕДОВАНИЯ}

\section{Изложение}

Введение: Отоакустические эмиссии на частоте продукта искажений (англ. Distortion Product Otoacoustic Emission - DPOAE) обычно измеряются до частоты 8 кГц. Однако, некоторые системы могут измерять DPOAE даже до 16 кГц. Поэтому целью этого исследования было проверить достоверность DPOAE для 10, 12, и 16 кГц. Также были сравнены измерения, при которых зонд подбирался однократно или многократно.

Материалы и методы: DPOAE измерялась у хорошо слышащих людей, у которых пороги слышимости были лучше либо 25 дБ НL для частот с 0,25 до 16 кГц. DPOAE была измерена для частот 1, 2, 4, 6, 8, 10, 12, и 16 кГц. В главную сферу интересов входили частоты в пределах 10-16 кГц, однако предел 1-8 кГц был использован для сравнения. Каждая измерительная сессия состояла из трех измерительных проб. Две первые пробы были выполнены поочередно без вынимания зонда - путем однократного подбора. Третья измерительная проба была выполнена после удаления, а затем вторичного введения зонда в наружный слуховой проход путем многократного подбора.

Результаты: Результаты показывают, что разница между измерениями была выше для частот в пределе 8-16 кГц, чем в пределе 1-6 кГц. Кроме того, разница была больше в случае многократного подбора по сравнению с однократным подбором.

Заключение: Измерение DPOAE для частот выше 8 кГц кажется достоверным. Однако, DPOAE на этих частотах более изменчивы, чем DPOAE на низких частотах.

Ключевые слова: отоакустические эмиссии на частоте продукта искажений • DPOAE • достоверность • изменчивость

\section{POWTARZALNOŚĆ EMISJI OTOAKUSTYCZNYCH PRODUKTÓW ZNIEKSZTAŁCEŃ DLA 10, 12 I 16 KHZ: BADANIA WSTEPNE}

\section{Streszczenie}

Wprowadzenie: Emisje otoakustyczne produktów zniekształceń (ang. Distortion Product Otoacustic Emission - DPOAE) mierzy się zazwyczaj do częstotliwości $8 \mathrm{kHz}$. Jednak niektóre systemy mogą mierzyć DPOAE aż do $16 \mathrm{kHz}$. Dlatego też celem tego badania było sprawdzenie wiarygodności DPOAE dla 10, 12 i $16 \mathrm{kHz}$. Porównano również pomiary, w których sonda była pojedynczo lub wielokrotnie dopasowana.

Materiał i metody: DPOAE mierzono u osób normalnie słyszących, u których progi słyszenia były lepsze bądź równe $25 \mathrm{~dB}$ HL dla częstotliwości od 0,25 do $16 \mathrm{kHz}$. DPOAE zmierzono dla częstotliwości 1, 2, 4, 6, 8, 10, 12 i $16 \mathrm{kHz}$. W głównym obszarze zainteresowania były częstotliwości z zakresu $10-16 \mathrm{kHz}$, natomiast zakres $1-8 \mathrm{kHz}$ służył jako porównanie. Każda sesja pomiarowa składała się z trzech pomiarów. Pierwsze dwa zostały wykonane kolejno bez wyjmowania sondy - w trybie pojedynczego dopasowania. Trzeci pomiar został wykonany po wyjęciu i ponownym wprowadzeniu sondy do przewodu słuchowego zewnętrznego - tryb wielokrotnego dopasowania.

Wyniki: Wyniki wskazują, że różnice pomiędzy pomiarami były wyższe dla częstotliwości w zakresie 8-16 kHz, niż w zakresie 1-6 kHz. Ponadto różnice były większe w przypadku wielokrotnego dopasowania w porównaniu do pojedynczego dopasowania.

Wnioski: Pomiar DPOAE dla częstotliwości powyżej $8 \mathrm{kHz}$ wydaje się być wiarygodny. Jednakże DPOAE dla tych częstotliwości mają większy rozrzut niż te dla niższych częstotliwości.

Słowa kluczowe: emisje otoakustyczne produktów zniekształceń • DPOAE • wiarygodność • powtarzalność

\section{Background}

Otoacoustic emissions (OAEs) are an established objective test of hearing [1]. Their advantage is that they can provide information about the status of the cochlea in a very short time [2]. A popular OAE type used for clinical purposes is distortion product OAEs (DPOAEs). Generally,
DPOAEs are known to give better indications of hearing at higher frequencies, i.e. above $1 \mathrm{kHz}$ [3].

In most systems nowadays DPOAEs are measured between 1 and $8 \mathrm{kHz}$. It is well known that hearing loss usually starts at higher frequencies [4]. Also, high frequency hearing loss affects OAEs at lower frequencies, and 


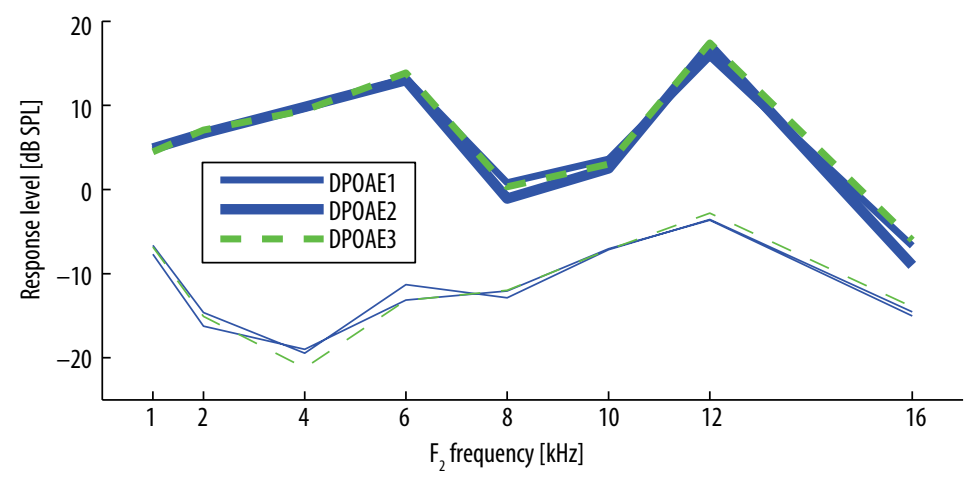

Figure 1. Average DPOAE levels for F2 frequencies from 1 to $16 \mathrm{kHz}$ for three measurements. The thick continuous lines are measurements made without refitting the probe (DPOAE1 and DPOAE2); the dashed line shows results after refitting the probe (DPOAE3). The thin lines represent the noise floor.

therefore OAEs can be good indicators for predicting preclinical changes in the cochlea [5-7]. Despite the fact that standard hearing tests examine frequencies only up to 8 $\mathrm{kHz}$, evaluating hearing status at higher frequencies may be crucial in such cases as monitoring noise exposure or ototoxicity $[8,9]$. OAEs seem to be a very good choice for such purposes, as the test is reliable, objective, and fast.

There are already some studies showing the diagnostic value of OAEs above $8 \mathrm{kHz}$. It has been shown that the amplitude of DPOAEs above $8 \mathrm{kHz}$ decreases before changes in audiometric tests can be observed [10]. In [11], high frequency DPOAEs have been recommended for screening schoolchildren. There are already commercial devices available capable of measuring DPOAEs above $8 \mathrm{kHz}$ - e.g. HearID (Mimosa Acoustics, Inc., USA); DP2000 (Starkey, USA); and SmartOAE (Intelligent Hearing Systems, USA). However, the current version of the system most commonly referenced in scientific papers (ILO 292, Otodynamics, UK) is only capable of measuring DPOAEs at frequencies up to $8 \mathrm{kHz}$.

When considering application of a diagnostic method, repeatability is of the highest importance. The betweensubject variability of OAEs is high $[12,13]$, although in the same subject OAEs are known to be stable over time when there is no hearing loss [14]. In the case of DPOAEs, the differences in response levels between measurements are reported to be around $3 \mathrm{~dB}$ [15]. These differences are larger at lower frequencies (below $1 \mathrm{kHz}$ ) and at higher frequencies (above $6 \mathrm{kHz}$ ).

Differences between measurements are reported to be greater when the probe is removed and reinserted back into the ear canal (multiple-fit) than when the probe is left intact in the ear canal between measurements (singlefit) [16]. When measurements made over several days are compared, many researchers find high stability of DPOAEs $[15,17,18]$.

The aim of this study was to investigate the properties of DPOAEs measured at frequencies above $8 \mathrm{kHz}$ by means of a commercially available device (Hear ID, Mimosa Acoustics). The reliability of DPOAEs at 10,12 , and $16 \mathrm{kHz}$ was of special interest. Comparisons were made between measurements made by keeping the probe in place and with measurements made after removing and reinserting the probe.

\section{Material and methods}

DPOAEs from 11 adults (24-42 years, 8 women, 3 men) were measured in low ambient noise conditions using a HearID system (Mimosa Acoustics, Inc., USA) running software version 5.1.3.0 and fitted with an ER-10C probe microphone (Etymotic Research, USA). All subjects were laryngologically healthy with no otoscopic ear abnormalities. In pure tone audiometry, hearing thresholds were 25 $\mathrm{dB} H \mathrm{HL}$ or better for frequencies from 0.25 to $16 \mathrm{kHz}$. As middle ear status may significantly affect OAE properties [19], only ears with type A tympanograms and normal acoustic reflexes were included in the study.

DPOAEs were evoked by two tones denoted as $\mathrm{F}_{1}$ and $\mathrm{F}_{2}$, and responses were measured at the frequency of $2 \mathrm{~F}_{1}-\mathrm{F}_{2}$. DPOAEs were measured at selected frequencies for $\mathrm{F}_{2}$ of $1,2,4,6,8,10,12$, and $16 \mathrm{kHz}$; the $\mathrm{F}_{2} / \mathrm{F}_{1}$ ratio was 1.2 ; and the stimulus levels were 65 and $55 \mathrm{~dB}$ SPL. The measurement settings used were the same as in some of the default protocols of the HearID system. The only change was a different frequency arrangement, with extension to 16 $\mathrm{kHz}$. Only recordings in which DPOAE level was at least $3 \mathrm{~dB}$ above the noise floor at all frequencies were accepted [20]. In total, 19 ears were analyzed (11 left, 8 right).

Each recording session consisted of three measurements. The first two were made consecutively without taking out the probe - single-fit mode (DPOAE1 and DPOAE2). The third measurement was made after taking out and refitting the probe - multiple-fit mode (DPOAE3).

Analyses were done in MATLAB version R2014 (The MathWorks, USA). For all parameters the statistical significance of the mean difference between groups was evaluated using the Wilcoxon rank sum test. This is equivalent to Student's $t$-test when the analyzed populations do not have normal distributions. As a criterion of significance, a $95 \%$ confidence level $(p<0.05)$ was chosen.

\section{Results}

In Figure 1, average DPOAE levels for $\mathrm{F}_{2}$ frequencies from 1 to $16 \mathrm{kHz}$ are shown for the three measurements (DPOAE1 and DPOAE2 were made without refitting the probe, and DPOAE3 was made after refitting the probe). There were no statistically significant differences between DPOAE1, DPOAE2, and DPOAE3. 


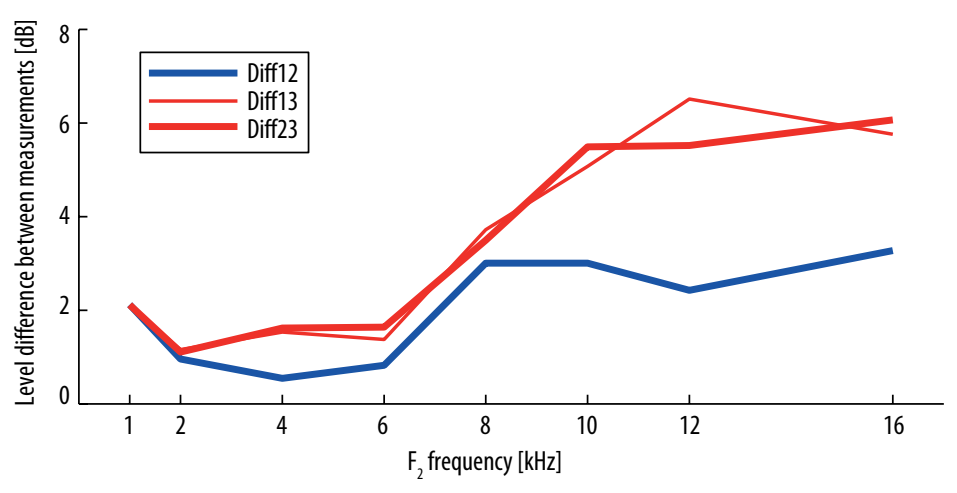

Figure 2. Average DPOAE level differences between measurements. The blue line denotes differences between two measurements made without refitting the probe (Diff12). The red lines represent differences between the same two measurements and a set made after refitting the probe (Diff13 and Diff23).
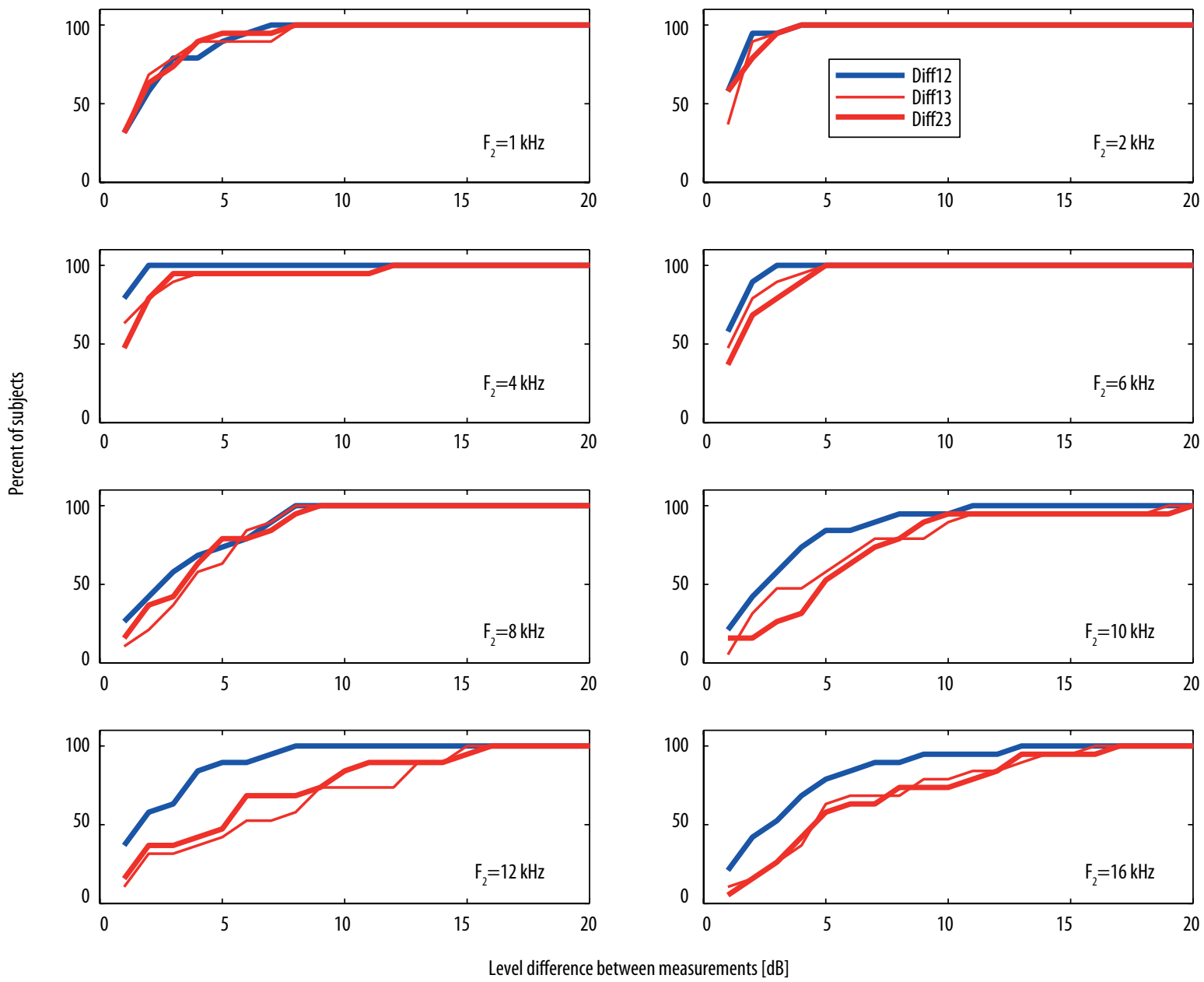

Figure 3. Cumulative plots of DPOAE level differences between measurements. The F2 frequency is indicated in each panel. The coding of the lines is the same as in Figure 2.

In Figure 2, average DPOAE absolute level differences between measurements are shown. Diff12 relates to differences without refitting the probe (DPOAE1-DPOAE2), while Diff13 and Diff23 relate to differences before and after probe refitting (DPOAE1-DPOAE3 and DPOAE2DPOAE3). It can be seen that Diff12 at $1 \mathrm{kHz}$ is around 2 $\mathrm{dB}$, it is close to $1 \mathrm{~dB}$ in the $2-6 \mathrm{kHz}$ range, and grows to around $3 \mathrm{~dB}$ in the $8-16 \mathrm{kHz}$ range. A similar pattern for Diff13 and Diff23 can be observed, although differences are now greater: below $2 \mathrm{~dB}$ in the $2-6 \mathrm{kHz}$ range and reaching $6 \mathrm{~dB}$ for $10-16 \mathrm{kHz}$. Diff13 and Diff23 are generally quite similar, with greater discrepancies in the 10 $16 \mathrm{kHz}$ range. Statistically significant differences between single-fit and multiple-fit (i.e. Diff12 and Diff13) were observed at 12 and $16 \mathrm{kHz}$, and for Diff12 and Diff23 at 4, 10,12 , and $16 \mathrm{kHz}$. Additionally, all differences (Diff12, Diff13, and Diff23) were statistically higher at $8-12 \mathrm{kHz}$ than at $2-6 \mathrm{kHz}$. 
Figure 3 shows cumulative percentage of ears in relation to DPOAE level differences between measurements. At frequencies of $2-6 \mathrm{kHz}$, differences in single-fit mode were less than $3 \mathrm{~dB}$ in nearly all ears, while in multiple-fit mode this was the case in only about $85 \%$ of ears. For frequencies of $8-16 \mathrm{kHz}$, differences up to $3 \mathrm{~dB}$ were observed in about $55 \%$ of ears in single-fit mode and even less in multiple-fit mode.

\section{Discussion}

The purpose of the study was to investigate the reliability of DPOAEs at very high frequencies. The results indicate that the inter-measurement variability is higher for frequencies in the $8-16 \mathrm{kHz}$ range than in the $1-6 \mathrm{kHz}$ range. The variability was higher for multiple-fit than for single-fit.

Response level patterns similar to [21] were obtained, with a decrease in level around $8 \mathrm{kHz}$, a rise at around $12 \mathrm{kHz}$, and then a decay to $16 \mathrm{kHz}$. The noise pattern was also similar, with a minimum at $4 \mathrm{kHz}$. Variability was similar to that found in [22], with DPOAEs at $8 \mathrm{kHz}$ having higher variability than at lower frequencies. As with [23], DPOAE variability was higher at $10 \mathrm{kHz}$ than at $2-7 \mathrm{kHz}$. Nevertheless, it is difficult to directly compare these results as the aforementioned study used different $\mathrm{F}_{2}$ frequencies and the subjects were children. In [16], only frequencies up to $6 \mathrm{kHz}$ were studied, although the same probe used here was employed. Of interest, slightly different results were obtained. The worst repeatability was at $6 \mathrm{kHz}$, with better results at 1-5 kHz for both single- and multiple-fit measurements.
Similarly to [24], the differences between measurements were higher at $8-16 \mathrm{kHz}$ than at $2-6 \mathrm{kHz}$. In [24], the cumulative percentage of subjects having a certain DPOAE level difference were investigated for the $9-15 \mathrm{kHz}$ range. For all these frequencies, the differences were $15 \mathrm{~dB}$ or less in all subjects. In comparison, in the present study the differences were about the same for 12 and $16 \mathrm{kHz}$, but at 8 and $10 \mathrm{kHz}$ they were slightly lower, around $10 \mathrm{~dB}$ (at least in the single-fit mode).

The greater variability of DPOAEs at higher frequencies has been explained in some studies by the interference of standing waves and by the greater effect of probe position in the ear canal $[23,25]$. The larger variability of DPOAE levels obtained in the present study for multiple-fit measurements could therefore be expected, and the measured magnitude was similar to previous studies $[16,18]$.

Despite the greater variability, OAEs at high frequencies (above $8 \mathrm{kHz}$ ) are a very promising option for extending the diagnostic value of OAE tests. There is still a need for more research on impaired ears, as there are not many results in this area.

\section{Conclusions}

Measurements of DPOAEs at frequencies above $6 \mathrm{kHz}$ appear reliable, since responses are repeatable and well above the noise floor. However, measurements do have higher variability than those made at lower frequencies.

\section{References:}

1. Lonsbury-Martin BL, Martin GK. Otoacoustic emissions. Curr Opin Otolaryngol Head Neck Surg, 2003; 11(5): 361-6.

2. Hatzopoulos S, Grzanka A, Martini A, Konopka W. New clinical insights for transiently evoked otoacoustic emission protocols. Med Sci Monit, 2009; 15(8): CR403-8.

3. Gorga MP, Neely ST, Bergman BM, Beauchaine KL, Kaminski JR, Peters J et al. A comparison of transient-evoked and distortion product otoacoustic emissions in normal-hearing and hearing-impaired subjects. J Acoust Soc Am, 1993; 94(5): 2639-48.

4. Robinson DW, Sutton GJ. Age effect in hearing: a comparative analysis of published threshold data. Audiology, 1979; 18(4): 320-34.

5. Arnold DJ, Lonsbury-Martin BL, Martin GK. High-frequency hearing influences lower-frequency distortion-product otoacoustic emissions. Arch Otolaryngol Head Neck Surg, 1999; 125(2): 215-22.

6. Dreisbach LE, Torre P, Kramer SJ, Kopke R, Jackson R, Balough $B$. Influence of ultrahigh-frequency hearing thresholds on distortion-product otoacoustic emission levels at conventional frequencies. J Am Acad Audiol, 2008; 19(4): 325-36.

7. Fabijańska A, Smurzyński J, Hatzopoulos S, Kochanek K, Bartnik G, Raj-Koziak D et al. The relationship between distortion product otoacoustic emissions and extended high-frequency audiometry in tinnitus patients. Part 1: normally hearing patients with unilateral tinnitus. Med Sci Monit, 2012; 18(12): CR765-70.
8. Kuronen P, Sorri MJ, Pääkkönen R, Muhli A. Temporary threshold shift in military pilots measured using convention$\mathrm{al}$ and extended high-frequency audiometry after one flight. Int J Audiol, 2003; 42(1): 29-33.

9. Fausti SA, Helt WJ, Phillips DS, Gordon JS, Bratt GW, Sugiura KM et al. Early detection of ototoxicity using 1/6th-octave steps. J Am Acad Audiol, 2003; 14(8): 444-50.

10. Mello JM, Della-Rosa VA, Carvallo RM. Distortion-product otoacoustic emissions at ultra-high frequencies in parents of individuals with autosomal recessive hearing loss. Codas, 2014; 26(1): 3-9.

11. Driscoll C, Kei J, Hearn K, Walsh T, Swann S. Diagnostic accuracy of high-frequency distortion-product otoacoustic emission screening of schoolchildren with Down syndrome. J Hear Sci, 2014; 4(1): 9-17.

12. Blinowska KJ, Jedrzejczak WW, Konopka W. Resonant modes and musical ratios in otoacoustic emissions. Biol Cybern, 2005; 93(5): 366-72.

13. Kochanek KM, Śliwa LK, Puchacz K, Piłka A. Repeatability of transient-evoked otoacoustic emissions in young adults. Med Sci Monit, 2015; 21: 36-43.

14. Hatzopoulos S, Petruccelli J, Ciorba A, Martini A. Optimizing otoacoustic emission protocols for a UNHS program. Audiol Neurootol, 2009; 14(1): 7-16.

15. Roede J, Harris FP, Probst R, Xu L. Repeatability of distortion product otoacoustic emissions in normally hearing humans. Audiology, 1993; 32(5): 273-81. 
16. Wagner W, Heppelmann G, Vonthein R, Zenner HP. Test-retest repeatability of distortion product otoacoustic emissions. Ear Hear, 2008; 29(3): 378-91.

17. Franklin DJ, McCoy MJ, Martin GK, Lonsbury-Martin BL. Test-retest reliability of distortion-product and transiently evoked otoacoustic emissions. Ear Hear, 1992; 13(6): 417-29.

18. Beattie RC, Kenworthy OT, Luna CA. Immediate and shortterm reliability of distortion-product otoacoustic emissions. Int J Audiol, 2003; 42(6): 348-54.

19. Bell A: How do middle ear muscles protect the cochlea? Reconsideration of the intralabyrinthine pressure theory. J Hear Sci, 2011; 1(2): 9-23.

20. Owens JJ, McCoy MJ, Lonsbury-Martin BL, Martin GK. Otoacoustic emissions in children with normal ears, middle ear dysfunction, and ventilating tubes. Am J Otol, 1993; 14(1): 34-40.
21. Dunckley KT, Dreisbach LE. Gender effects on high frequency distortion product otoacoustic emissions in humans. Ear Hear, 2004; 25(6): 554-64.

22. Keppler H, Dhooge I, Maes L, D’haenens W, Bockstael A, Philips B et al. Transient-evoked and distortion product otoacoustic emissions: a short-term test-retest reliability study. Int J Audiol, 2010; 49(2): 99-109.

23. Sockalingam R, Lee Choi J, Choi D, Kei J. Test-retest reliability of distortion-product otoacoustic emissions in children with normal hearing: a preliminary study. Int J Audiol, 2007; 46(7): 351-4. Erratum in: Int J Audiol, 2009; 48(6): 403.

24. Dreisbach LE, Long KM, Lees SE. Repeatability of high-frequency distortion-product otoacoustic emissions in normalhearing adults. Ear Hear, 2006; 27(5): 466-79.

25. Zebian M, Hensel J, Fedtke T, Vollbort S. Interpretation of distortion product otoacoustic emissions at higher frequencies. J Hear Sci, 2011; 1(3): 49-51. 